\title{
Decapod crustaceans used as food by the Yanomami Indians of the Balawa-ú village, State of Amazonas, Brazil.
}

\author{
Célio MAGALHÃES ${ }^{1,2}$, Ulysses C. BARBOSA ${ }^{1} \&$ Victor PY-DANIEL $^{1}$
}

\begin{abstract}
The Yanomami are a group of South American Indians that live in the rainforest along the borderlands of Brazil and Venezuela. They depend on hunting, gardening and wild food for survival; crustaceans are a highly prized food item in their diet. Taxonomical and ethnozoological aspects of the Yanomami Indians of the Balawa-ú village, state of Amazonas, Brazil, related to the crustaceans are described. Information and specimens were obtained from August to December, 2003. Interviews were conducted with residents of the village and focused on questions about species exploited, indigenous names, modes of capture and use of the species. One shrimp species of the family Palaemonidae (Macrobrachium brasiliense) and two crab species of Trichodactylidae (Sylviocarcinus pictus, Valdivia serrata) as well as two of Pseudothelphusidae (Fredius fittkani, F. platyacanthus) were recorded. The indigenous names applied to these species are: shuhu, for shrimp, oko and peimatherimi for each of the two pseudothelphusid crabs, and hesiki tôtôrema for both trichodactylid crabs.
\end{abstract}

KEY WORDS

Ethnozoology, Yanomami Indians, Amazon region, freshwater decapod, indigenous name

\section{Crustáceos decápodos usados na alimentação pelos índios Yanomami da aldeia de Balawa-ú, Estado do Amazonas, Brasil.}

\begin{abstract}
RESUMO
Os Yanomami são um grupo de indios que habitam a floresta tropical úmida ao longo da fronteira entre Brasile Venezuela. Eles dependem da caça, da agricultura e da coleta de produtos da floresta para a sua sobrevivência, sendo os crustáceos um dos itens alimentares mais apreciados. São descritos aspectos taxonômicos e etnozoológicos dos indios Yanomami da aldeia de Balawa-ú, no estado do Amazonas, Brasil, relacionados aos crustáceos. Informaçôes e espécimes foram coletados de agosto a dezembro de 2003. Foram realizadas entrevistas com habitantes da aldeia com enfoque nas espécies exploradas, nomes indígenas, modos de captura e utilização. Foram registradas uma espécie de camarão da família Palaemonidae (Macrobrachium brasiliense), duas espécies de caranguejos da familia Trichodactylidae (Sylviocarcinus pictus, Valdivia serrata) e duas da familia Pseudothelphusidae (Fredius fittkaui, F. platyacanthus). Os nomes indigenas usados para elas são: shuhu, para o camarão, oko e peimatherimi para cada um dos caranguejos pseudotelfusídeos, e hesiki tôtôrema para ambas as espécies de caranguejos tricodactilídeos.
\end{abstract}

\section{PALAVRAS-CHAVE}

Etnozoologia, indios Yanomami, regiāo amazônica, decápodos de água doce, nome indígena

\footnotetext{
${ }^{1}$ Instituto Nacional de Pesquisas da Amazônia, Caixa Postal 478, 69011-970 Manaus, AM, Brasil. E-mail: (celiomag, ulysses, pydaniel@inpa.gov.br)

${ }^{2}$ Research Fellow of the Conselho Nacional de Desenvolvimento Científico e Tecnológico - CNPq
} 


\section{INTRODUCTION}

The Yanomami tribes are a group of South American Indians who live in the Amazon rainforest, spread over a territory of approximately $192,000 \mathrm{~km}^{2}$, most of which is located along the highlands and mountainous region in both northern Brazil and southern Venezuela. The most populated area is situated in the Parima Mountains, between the headwaters of the Rio Orinoco (on the Venezuelan side), and the Rio Parima, Rio Mucajaí, and Rio Catrimani (on the Brazilian slope). They are made up of four adjacent subgroups, divided according to linguistic subdivisions: Yanomae, Yanomami, Sanima e Ninam (Ramirez, 1999).

Cocco (1987) and Chagnon (1997) described several aspects of their society, culture and way of living, as well as information about their diet. Ethnobotany was studied by Milliken \& Albert (1996a,b), who described their use of medicinal plants and gave a general overview of their use and knowledge of plants (Milliken \& Albert, 1999). Finkers (1986) presented a detailed study about the Yanomami alimentary system. References to other studies can be found in Chagnon (1997) and Milliken \& Albert (1999).

According to Finkers (1986), Cocco (1987), Lizot (1988), and Chagnon (1997), crustaceans are a prized food item in the Yanomami diet, but they offered only a few details about the species or how they are captured and used. Cocco (1987) mentioned some Yanomami names for shrimp and crabs and the way they eat them. Finkers (1986) presented a table relating the Yanomami name with the Spanish name of some invertebrates in which shrimp and crabs are included. However, none of these authors related the Yanomami name with the respective scientific name of the crustaceans used by the indians.

In this study we determine the taxonomy of the species of decapod crustaceans used as food by the Yanomami Indians from the Balawa-ú village, state of Amazonas, Brazil, compare their indigenous and scientific names, as well as briefly document the way they are captured and used.

\section{MATERIAL AND METHODS}

The Balawa-ú village is situated at $01^{\circ} 47,91^{\prime} \mathrm{N} 63^{\circ} 46,88^{\prime} \mathrm{W}$ in dense lowland rainforest at the foot of the southern slope of the Serra do Urucuzeiro, near the border with Venezuela. Geologically, the area is part of the Pre-Cambrian Guyana Shield. The village lies near small forest streams, but distant from any large river. It is in the headwaters of the Rio Demini, a left tributary of the upper Rio Negro basin. Further details about the area can be found in Milliken \& Albert (1999).

Information and specimens were obtained during monthly field trips to the area while working on a project on human onchocerciasis vector from August to December, 2003. Interviews were conducted by one of us (UCB) with Yanomami women and children, who are the ones responsible for collecting such kind of food resources in the village, and focused on questions about species exploited, indigenous names, modes of capture and use of the species. The interviews were intermediated by a Yanomami woman, Jadete Yanomami, who acted as the spokesperson for the group. The information was posteriorly confirmed with the "tuchaua" (tribe leader), Geraldo Yanomami. Samples of each species in conditions for identification were collected by Jadete Yanomami. These specimens were preserved in $70 \%$ ethanol, and identification was based on the current taxonomic literature (Magalhães \& Rodríguez, 2002; Magalhães, 2003; Melo, 2003). The word "gonopod" refers to the male first sexual pleopod of the crabs, whose morphology is the base for their systematics (Smalley, 1964; Rodríguez, 1982; Magalhães, 2003). Voucher specimens are deposited in the Crustacean Collection of the Instituto Nacional de Pesquisas da Amazônia (INPA), Manaus, Brazil.

\section{RESULTS}

Crustaceans are usually collected by women and children. Shrimps and aquatic crabs (Sylviocarcinus pictus and Valdivia serrata) were captured with sieve-like baskets; terrestrial crabs (Fredius fittkaui and F. platyacanthus) were captured with bare hands, immobilized and rolled up with leaves, wrapped up with a liana strip and then deposited in a basket for transportation to the village. Shrimps and crabs are eaten cooked or roasted on coals. When large quantities are available, they are rolled up in leaves of Calathea sp. (Marantaceae) and then roasted. They are often eaten with green bananas roasted on coals (Musaceae: Musa spp.) or cooked cassava (Euphorbiaceae: Manihot esculenta). All internal organs are consumed and the exoskeleton is discarded.

Five species of freshwater decapod crustaceans were captured (one shrimp and four crabs belonging to three families) and their local Yanomami names related to the respective scientific name (Table 1). The species are the following:

Table 1 - List of decapod crustaceans captured in the Yanomami village of Balawa-ú, state of Amazonas, Brazil, with the scientific/indigenous name correspondence.

\begin{tabular}{ccc}
\hline & \multicolumn{2}{c}{ Species } \\
\cline { 2 - 3 } Family & Scientific name & Yanomami name \\
\hline Palaemonidae & Macrobrachium brasiliense (Heller) & Shuhu \\
Pseudothelphusidae & Fredius fittkaui (Bott) & Oko \\
& Fredius reflexifrons (Ortmann) & Peimatherimi \\
Trichodactylidae & Sylviocarcinus pictus & Hesiki tôtôrema \\
& (H. Milne-Edwards) & Hesiki tôtôrema \\
\hline
\end{tabular}




\section{FAMILY PALAEMONIDAE}

Macrobrachium brasiliense (Heller)

(Fig. 1)

Material.- Brasil, Amazonas: Balawa-ú village, unamed forest stream at Posto Yano, 7.x.2003, 1 đ 3 ovigerous (INPA 1336).

Remarks.-This species has a wide distribution range from Venezuela to southern Brazil (Melo 2003) and it is one of the few South American palaemonid shrimps that occcur in altitudes higher than $300 \mathrm{~m}$. In the Balawa-ú village, the shrimps are found among the submerged leaf litter, wood debris and stones in the sandy botton of streams. The species was recognized by its short, straight rostrum, which does not exceed the length of the antennular peduncle, and its well developed second cheliped, which has a subcylindrical palm and a dactylus/palm ratio lesser then 0.5 in full grown adults.

\section{FAMILY PSEUDOTHELPHUSIDAE}

Fredius fittkaui (Bott)

(Figs. 2, 6)

Material.- Brasil, Amazonas: surroundings of Balawa-ú village, 6.x.2003, 3 o 2 (INPA 1330).

Remarks.- This is a large (carapace breadth $>60 \mathrm{~mm}$ ) terrestrial species that is commonly found in moist areas of the forest floor, usually inside burrows close to tree roots and not very far from the water body. It is distributed in the upper Rio Negro basin, mainly in the left bank tributaries, but its geographical range encompasses Venezuela, Brazil and Guyana (Magalhães \& Rodríguez 2002).

F. fittkaui has a elipsoid carapace shape in dorsal view and the last segment (dactylus) of the ambulatory legs shows distinct rows of corneous spines. The lateral margins of the carapace has a rather smooth appearance, but are bordered by a series of small rounded tubercles in closer view. The carapace is usually dark or dark brown. However, the species is identified by the gonopod morphology, which is robust at base, narrower at middle, and bears a well developed subapical bulge around lateral and cephalic sides. A detailed description is given by Magalhães \& Rodríguez (2002).

\section{Fredius platyacanthus Rodríguez \& Pereira}

(Figs. 3, 7)

Material.- Brasil, Amazonas: surroundings of Balawa-ú village, 12.xi.2003, 2 \% 1 \% (INPA 1328).

Remarks. - This is also a large terrestrial species and, apparently, syntopic with $F$. fittkaui. Up to now, the species was only known from its type locality, in El Abismo, Rio Icabaru, state of Bolivar, Venezuela (Rodríguez \& Pereira 1992), which lies in the upper Rio Caroni (Orinoco basin), northern slope of Serra de Pacaraima.
The present record in the Amazon basin extends farther southwards the distributional range of the species, indicating that it has a transbasin distribution.

F. platyacanthus has a carapace morphology nearly identical to that of $F$. fittkaui, and their taxonomic differentiation must be done based on the gonopodal characteres. The gonopod of $F$. platyacanthus is robust at base and tapers distinctly towards a subapical bulge, with apex bearing well developed marginal, cephalic, and mesial lobes. A careful description can be found in Rodríguez \& Pereira (1992).

\section{FAMILY TRICHODACTYLIDAE}

Sylviocarcinus pictus (H. Milne-Edwards)

(Figs. 4, 8)

Material.- Brasil, Amazonas: surroundings of Balawa-ú village, 5.ix.2003, 1 ๙ 1 \% (INPA 1331); idem above, 12.xi.2003, $2 \sigma^{\star}$ (INPA 1333); idem above, 1-5.xii.2003, $15 \sigma^{\star}$ 4 ㅇ (INPA 1335).

Remarks.-The species has a moderate size (carapace breadth usually $<60 \mathrm{~mm}$ ) and is primarily aquatic, although it can occasionally be found out of water. It occurs in the Guianas, Brazil, Colombia, Peru and Bolivia, has a wide distribution throughout the Amazon basin, and occupies different types of habitats (Magalhães, 2003). In the stream near the Balawa-ú village, it was found in the sandy botton of the stream.

This species has a subcircular carapace, with three to four triangular, acute teeth in the anterolateral margin, which however can fade away in larger specimens, and a slightly bilobed, smooth frontal margin. The carapace, usually pale brown with small reddish dots spread throughout, is regularly convex in both anteroposterior and lateral directions. The gonopod is slender and its axis is nearly straight; there is a subdistal lobe present in the laterodistal border and the distal opening is long and narrow.

\section{Valdivia serrata White}

(Figs. 5, 9)

Material.- Brasil, Amazonas: surroundings of Balawa-ú village, 1-5.xii.2003, 1 \% 1 o (juveniles) (INPA 1334).

Remarks.- This is a moderate sized species and primarily aquatic. It is usually associated with the submerged leaf litter and wood debris. In the stream near the Balawa-ú village it was found in the sandy botton of the stream. Its distributional range is very wide, encompassing the Orinoco and Amazon basins (Magalhães, 2003) in Venezuela, Guianas, Colombia, Brasil, and Bolivia. The voucher male specimen is a juvenile, but the species can be identified by the gonopodal morphology.

$V$. serrata has a subhexagonal carapace, with four to five large, acute teeth in the anterolateral margin, and a nearly straight 
ACTA

AMAZONICA
DECAPOD CRUSTACEANS USED AS FOOD BY THE YANOMAMI INDIANS OF

THE BALAWA-Ú VILLAGE, STATE OF AMAZONAS, BRAZIL.
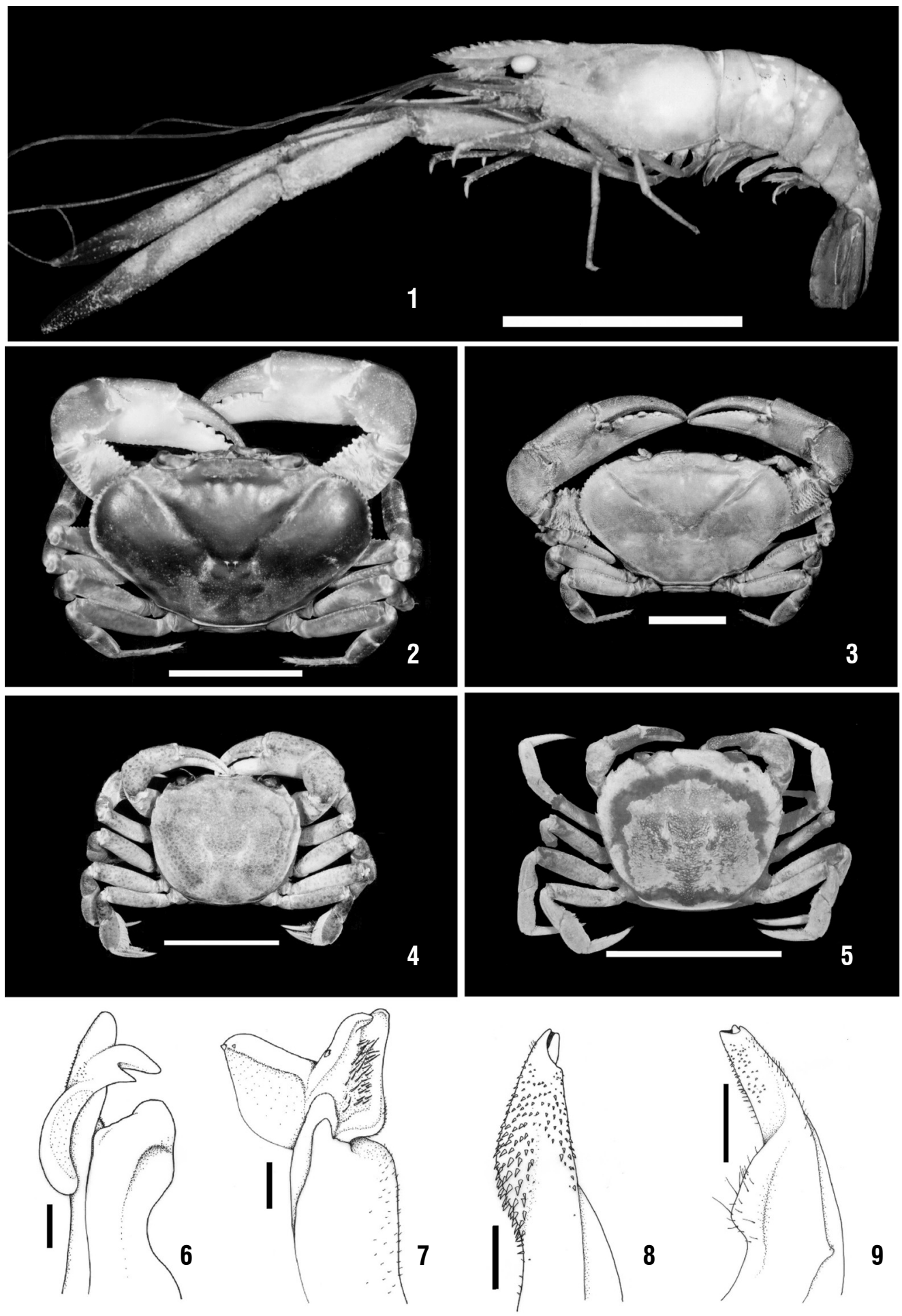

Figures 1 - 9 - Decapod crustaceans captured in the Yanomami village of Balawa-ú, state of Amazonas, Brazil. 1, Macrobrachium brasiliense (Heller), lateral view, INPA 1336. Fredius fittkaui (Bott), INPA 1330: 2, dorsal view; 6, male first gonopod, mesiocaudal view. Fredius platyacanthus Rodríguez \& Pereira, INPA 1328: 3, dorsal view; 7, male first gonopod, laterocaudal view. Sylviocarcinus pictus (H. Milne-Edwards), INPA 1335: 4, dorsal view; 8, male first gonopod, mesiocaudal view; 5, Valdivia serrata White, INPA 1334: 5, dorsal view; 9, male first gonopod, mesiocaudal view. Scale bars: figs $1-5=30 \mathrm{~mm}$; figs $6-9$ $=1 \mathrm{~mm}$. 
frontal margin. The carapace, usually light brown, is quite uneven with well marked grooves and crests. The gonopod is thicker in the proximal two third, being disctinctly curved in a ventrolateral direction; the lateroventral border has a distinct subretangular lobe in a median position, and the distal opening is very narrow.

The two trichodactylid species can be easily recognized from the pseudothelphusid by the shape of the carapace (subcircular or subhexagonal in the former, ellipsoid in the latter) and the ornamentation of the last segment (dactylus) of the ambulatory legs (setaceous in trichodactylids, spiny in pseudothelphusids).

\section{DISCUSSION}

The Yanomami make their survival on hunting, gardening and collecting wild food (Finkers, 1986; Cocco, 1987; Chagnon, 1997). They live deep in the forest and usually avoid larger streams (Chagnon, 1997). Even so, aquatic animals are a valuable source of protein in their diet (Finkers, 1986; Cocco, 1987). The five species of decapod crustaceans (one of shrimp and four of crabs) exploited by the indians from the Balawa-ú village is relatively high when one considers that the number of decapod species recorded from the northern tributaries of Rio Negro is around ten (Tiefenbacher, 1978; Kensley \& Walker, 1982; Magalhães \& Rodríguez, 2002; Magalhães, 2003). However, the diversity of the carcinological fauna in headwater environments is lower than in lowland habitats. Although the faunistic survey was not exhaustive, the species recorded from the Balawa-ú village would be the one expected for such an environment. The palaemonid shrimp and both trichodactylid species are eurytopic and are commonly found in the upper course of rivers, while the crabs of the genus Fredius are terrestrial, with distributions associated with the forest of the Guyana Shield region (Rodríguez \& Pereira, 1992; Magalhães \& Rodríguez, 2002).

The indigenous terms for decapods can vary among the Yanomami people according to their linguistic subdivisions or even among tribes. Working in Venezuela with tribes from the upper Orinoco basin, Finkers (1986: 147) listed names used by the tribes from the Rio Mavaca that are slightly different from those given by Cocco (1987) from the tribes of the Rio Ocampo. The latter author listed the words naki-hewasimi, peimaki-teri, and totori-oko for some crab species, and xuu-hupë for shrimp, while the former author recorded the words hewashimi and peimatherimi for some crabs, and shubu for shrimp. The indians from the Balawa-ú village use the same names as those listed by Finkers (1986). In addition, they have the word hesiki tôtôrema for the two trichodactylid crabs mentioned above.

Finkers (1986) listed the name hewashimi for a crab that he stated to be "smaller than the oko". We were not able to get a sample of this species, as the Balawa-ú people told us that this species is only found under rocks at the source of streams situated in higher parts of the mountains, very far from the village. Whether this is a different species remains to be confirmed, but other pseudothelphusid species (Fredius chaffanjon $i$ and F. estevisi siapensis) are known to occur in nearby regions such as the upper Rio Orinoco, in Venezuela (Rodríguez \& Pereira, 1992). Finkers (1986) also recorded the word horahesi as refering to small crabs. We verified that, at least for the Yanomami from Balawa-ú village, this word is applied to the giant water bugs (Hemiptera: Belostomatidae) and other aquatic insects, such as the water scavenger beetles (Coleoptera: Hydrophilidae) or the predaceous diving beetle (Coleoptera: Dyticidae).

The word $o k o$ seems to be a general term for crabs (Finkers, 1986; Cocco, 1987), but the Balawa-ú people made a clear distinction between the two pseudothelphusid species. Although F. fittkaui and $F$. platyacanthus are indistinguishable by their carapace morphology (Figs. 2, 3), they called oko for F. fittkaui and peimatherimi for F. platyacanthus. Although S. pictus and $V$. serrata, on the other hand, have distinct carapace morphology (Figs. 4, 5), the indians use only one term (hesiki tôtôrema) for both.

As Cocco (1987) and Chagnon (1997) have already mentioned, we noticed that the decapods are a highly prized delicacy also for the Yanomami from the Balawa-ú village. The pseudothelphusid (oko and peimatherimi) are preferred to the trichodactylid (hesiki tôtôrema) species. Finkers (1986) also mentioned that they are roasted directly on coals, or when numerous, inside rolled leaves, usually from pisha (Family Marantaceae), kumishi (Palmae), mokoro (Marantaceae), shirekomi or ketipa (both Musacea). Lizot (1988), when describing the confinement ritual of a Yanomami girl during the first mestruation, mentioned that her sole gastronomical delight is to suck a crab exoskeleton.

\section{ACKNOWLEDGMENTS}

The authors wish to thank Geraldo and Jadete Yanomami for their help with information and for collecting the specimens, G. Nakamura for revising the English, the Ministério da Saúde - Programa de Controle da Oncocercose and OEPA (Onchocerciasis Elimination Program for the Americas) for providing research funds, and the Conselho Nacional de Desenvolvimento Científico e Tecnológico - $\mathrm{CNPq}$ for a research grant.

\section{LITERATURE CITED}

Chagnon, N. A. 1997. Yanomamö. $5^{\text {th }}$ ed. Hartcourt Brace College Publishers, Fort Worth. 280pp.

Cocco, L. 1987. Iyëwei-teri. Quince años entre los Yanomamos. $2^{\text {nd }} e d$. Libreria Editorial Salesiana y Escuela Técnica Popular Don Bosco, Caracas. 498pp.

Finkers, J. 1986. Los Yanomami y su sistema alimenticio (Yanomami 


\section{ACTA
AMAZONICA}

DECAPOD CRUSTACEANS USED AS FOOD BY THE YANOMAMI INDIANS OF

THE BALAWA-Ú VILLAGE, STATE OF AMAZONAS, BRAZIL.

Nit Pë). Vicariato Apostólico de Puerto Ayacucho, Puerto Ayacucho. Monografía n 2. 262pp.

Kensley, B.; Walker, I. 1982. Palaemonidae shrimp from the Amazon basin (Crustacea: Decapoda: Natantia). Smithsonian Contribution to Zoology, 362: 1-28.

Lizot, J. 1988. O Círculo dos Fogos. Feitos e Ditos dos Índios Yanomami. Martins Fontes, São Paulo (Translated by Beatriz Perrone Moysés). 230pp.

Magalhães, C. 2003. Famílias Pseudothelphusidae e Trichodactylidae. In: Melo, G. A. S. (Ed.). Manual de Identificação dos Crustáceos Decápodos de Água Doce Brasileiros. Editora Loyola, São Paulo. p. $143-287$

Magalhães, C.; Rodríguez, G. 2002. The systematic and biogeographical status of Fredius reflexifrons (Ortmann, 1897) and Fredius fittkaui (Bott, 1967) (Crustacea: Brachyura: Pseudothelphusidae) from the Amazon and Atlantic Guianas river basins. Acta Amazonica, 32(4): 677-689.

Melo, G. A. S. 2003. Famílias Atyidae, Palaemonidae e Sergestidae. Melo, G. A. S. (Ed.). Manual de Identificação dos Crustáceos Decápodos de Água Doce Brasileiros. Editora Loyola, São Paulo. p. 289-415.

Milliken, W.; Albert, B. 1996a. The use of medicinal plants by the Yanomami Indians of Brazil. Economic Botany 50(1): 10-25.

Milliken, W.; Albert, B. 1996b. The use of medicinal plants by the
Yanomami Indians of Brazil. Part II. Economic Botany 51(3): 264-278.

Milliken, W.; Albert, B. (with colaboration of Gale Goodwin Gomez). 1999. Yanomami a Forest People. Kew, The Royal Botanic Gardens. 161pp.

Smalley, A. 1964. A terminology for the gonopods of the American river crabs. Systematic Zoology 13: 28-31.

Ramirez, H. 1999. Iniciação à língua Yanomami. Boa Vista, Diocese de Roraima. 77pp.

Rodríguez, G. 1982. Les crabes d'eau douce d'Amerique. Famille des Pseudothelphusidae. Faune Tropicale, 22. ORSTOM, Paris. 224pp.

Rodríguez, G.; Pereira, G. 1992. New species, cladistic relationships and biogeography of the genus Fredius (Crustacea: Decapoda: Pseudothelphusidae) from South America. Journal of Crustacean Biology 12: 298-311.

Tiefenbacher, L. 1978. Zur sistematik und verbreitung der Euryrhynchinae (Decapoda, Natantia, Palaemonidae). Crustaceana 35(2): 177-189.

Recebido em 03/06/2005

Aceito em 26/05/2006 